\title{
Gram per Hour
}

National Cancer Institute

\section{Source}

National Cancer Institute. Gram per Hour. NCI Thesaurus. Code C85601.

Grams per hour. 